Marquette University

e-Publications@Marquette

Theology Faculty Research and Publications

Theology, Department of

$1-1-2001$

\title{
Analogy and Metaphoric Process
}

Robert Masson

Marquette University, robert.masson@marquette.edu

Published version. Theological Studies, Vol. 62, No. 3 (2001): 571-596. Publisher Link. (C) 2001 Theological Studies, Inc. Used with permission. 


\title{
ANALOGY AND METAPHORIC PROCESS
}

\author{
ROBERT MASSON
}

[The author argues that the dispute between Elizabeth Johnson and Joseph Bracken about the doctrine of God is rooted in a disagreement about how we know and speak of God. The difference is characterized as a choice between one view that sees theology's task as finding appropriate analogies for conceiving God and another view governed by the assumption that a more fundamental metaphoric shift in thinking and speaking is required. This article clarifies what is at issue by analyzing other conceptions of analogy in the light of a specific theory of metaphoric process.]

$\mathrm{T}$

HE FUNDAMENTAL DISAGREEMENT in a conversation is not always the apparent one, especially if it entails negotiating differences between metaphysical or theological perspectives. The nature of divine providence appears to be the point at issue in the conversation between Elizabeth Johnson $^{1}$ and Joseph Bracken ${ }^{2}$ in articles published in Theological Studies (1996) as well as in subsequent discussions. ${ }^{3}$ Does process theology or a contemporary revision of Thomism provide a better paradigm for elaborating the doctrine and for responding to questions raised by the contemporary scientific worldview? My contention here is that a more fundamental issue is at the root of their disagreement: how do we know and speak of God at all? Their arguments presuppose fundamentally different answers.

Robert MAsson is associate professor of theology at Marquette University. He received his Ph.D. at Fordham University. In addition to his research into the theology of Karl Rahner (editing also the annual "Rahner Papers" for the journal Philosophy and Theology), he studies especially the function of religious language and knowledge in our theoretical, doctrinal, and practical understanding of God, Christ, and theological anthropology.

${ }^{1}$ Elizabeth A. Johnson, "Does God Play Dice? Divine Providence and Chance," Theological Studies 57 (1996) 3-18.

${ }^{2}$ Joseph A. Bracken, "Response to Elizabeth Johnson's 'Does God Play Dice?' " Theological Studies 57 (1996) 720-30.

${ }^{3}$ See Nancy A. Dallavalle, "Trinitarian Theology" and William R. Stoeger, "Theology and the Natural Sciences" Catholic Theological Society of America, Proceedings 53 (1998) 130-31, and 135-36. See also Bracken's subsequent essay, "The Theology of God of Elizabeth A. Johnson," in Things New and Old: Essays on the Theology of Elizabeth A. Johnson, ed. Phyllis Zagano and Terrence W. Tilley (New York: Crossroad, 1999) 21-38; and Johnson's response, "Forging Theology: A Conversation with Colleagues," in Things New and Old 91-123. 
Hence, Bracken's critique does not effectively engage Johnson's position. This failure of engagement demonstrates why attention to the metaphoric character of language and thinking about God is crucial to understanding the logic of religious signification and is crucial to the dialogue between theology and science.

\section{A CHOICE BETWEEN TWO WORLD VIEWS}

At the CTSA discussion, Bracken summarized the differences between their positions as "a choice between two world views, with one worldview basically governed by the logic of objective cause-effect relationships and the other ruled by. . .the logic of intersubjectivity." "His "quarrel is not with Johnson's conclusions but with the metaphysical conceptuality she uses to get there." Johnson responded that Bracken was objecting to an "ahistorical 'Cajetan' reading" of Thomism rather than the interpretation she espouses that appeals to Aquinas's analogical use of being as "a 'limit concept,' not a noun." ${ }^{\prime 6}$ Bracken was not persuaded that this line of response addresses the logical flaw that he believes is entailed in Thomism. ${ }^{7}$ I believe he resists because their disagreement is rooted in a more fundamental decision about how religious and metaphysical concepts signify. Insofar as their choices are indeed between two world views, it should not be surprising to find each describing the alternatives differently and even proposing interpretations of each other's positions that, despite obvious good will, might appear from the other's perspective to be misreadings.

What to call these two world views or how to describe them, therefore, is itself a point of contention. Johnson's retrieval of Thomism and Bracken's adaptation of Whitehead ultimately share a common philosophical heritage and use similar terms, understood, however, in significantly, but also sometimes subtly, different ways. That, I suspect, is why Bracken never directly responds to Johnson's explanation that she uses "being" analogically as a "limit concept," or why Johnson might view as nonresponsive his appeals to: the doctrine of analogy, Ian Barbour's notion of models, or the need for metaphysical rigor in the face of a trend toward overemphasis on God's incomprehensibility. Hence, although there are designations for these two world views ready to hand, they too would be highly contestable. That would be the difficulty with simply appropriating Rahner's distinction between the ontic and ontological to describe the difference between Bracken's and Johnson's conceptualizations of God; so

${ }^{4}$ Dallavalle, "Trinitarian Theology" 130.

5 Johnson, "Response to Elizabeth Johnson's 'Does God Play Dice?' " 730.

"Dallavalle, "Trinitarian Theology" 130.

7 Ibid. 131. 
too with Heidegger's differentiation between the logic of metaphysics (or onto-theology) and the logic of the holy (or the e-vent of truth); or with Thomas Sheehan's further refinement of these as a contrast between ousiological and kinetic thinking. ${ }^{8}$ Each gets at something of the difference in question. But each carries freight of its own and, in any case, Bracken could object that such distinctions are in fact accounted for more adequately in process theology's affirmation that "being is an activity rather than an entity." Hence I shall propose my own designation for the two world views at the root of their disagreement and, in what follows, assume the burden of explaining the choice and offering something of a justification for it. In this, I am guilty of using their exchange as a pretext for making a point about how knowledge and language signify God, just as Bracken's critique of Johnson's article was in fact something of a pretext for advancing his proposal for a Whiteheadian notion of intersubjectivity as a model for conceptualizing God.

\section{Classical Theism: A Red Herring}

If ground is to be cleared for a more fundamental engagement between these two world views, it is important not to get caught up too quickly in process theology's confrontation with "classical theism." I hope in the argument that follows to demonstrate that Bracken's critique of Thomism is something of a red herring. In the meantime, three reasons can be suggested for waiting until later to engage directly the issue as he has framed it. First, although Bracken is attentive to Johnson's claims and language, at a number of key junctures he assumes common philosophical meanings within his discourse and her's without first establishing that they are actually talking about the same matters. I argue that this is clearly an issue with the doctrine of analogy and the conception of being, and that as a matter of fact Johnson and Bracken mean very different things when they use these terms.

Second, Bracken ties much of his case to his characterization of the logic of Thomism and the contention that Johnson cannot avoid certain mistaken entailments of that logic. He follows a line of argumentation typical for process thinkers. Justification for their arguments gets tied up with a critique of "classical theism." Proving the inadequacies of the other position becomes ingredient to supporting their own, and vice versa, supporting

${ }^{8}$ Thomas Sheehan, Karl Rahner: The Philosophical Foundations (Athens: Ohio University, 1987).

${ }^{9}$ Joseph A. Bracken, The Divine Matrix: Creativity as Link between East and West (Maryknoll, N.Y.: Orbis, 1995) 37. See also the most recent articulation of his position in The One in the Many: A Contemporary Reconstruction of the God-World Relationship (Grand Rapids: Eerdmans, 2001). 
the other position is taken as a challenge to process theology's viability. Tying exposition and criticism so closely makes initial assessment of either position on its own merits more complicated and difficult than needs to be. Anyone who is sympathetic to Johnson's position and who judges Bracken's attribution of "classical theistic" maneuvers to be inaccurate or forced is likely to be left with an impression that his critique is at best a misunderstandıng, or at worst a misrepresentation. Moreover, as David Burrell argued in this journal some time ago, linking the justification for process theology to its critiques of "classical theism" makes its own case more vulnerable since then a failure on any of these counts undermines the position as such. ${ }^{10}$

A third reason to avoid getting caught up in the debate about "classical theism" is suggested by a lesson that might be taken from Bracken's own work. His creative modifications of process thought have shown resources within that tradition for at least addressing limitations that, according to critics like Burrell, are inherent in the logic of the position (for example, whether process thought can provide for an account of anything like the Christian doctrine of the Trinity or a personal God). ${ }^{11}$ Should not Bracken allow for the possibility that others might have effected analogous modifications of Thomism? Better to aim at a genuinely mutual engagement before committing to incommensurable counter positions.

\section{ANALOGIES AND THE ANALOGY OF BEING}

Equivocation on fundamental conceptions poses a significant obstacle for such engagement. This appears to be the situation when Bracken and Johnson appeal to the analogous character of assertions about God. They have different conceptions in mind. Bracken insists that "the principle of analogy, after all, requires that the entities under comparison have something in common as well as fundamental differences. Otherwise analogy turns out to be equivocation; the same term, 'being,' then has totally different meanings when applied to God and creatures." ${ }^{12}$ For this reason, he

${ }^{10}$ David Burrell, "Does Process Theology Rest on a Mistake?" Theological Studtes 43 (1982) 125-35

${ }^{11}$ In addition to Bracken's The Divine Matrix, see his Society and Sptrit A Trintarian Cosmology (Cranbury, N J : Susquehanna University, 1991) and "Subsistent Relation. Mediatıng Concept for a New Synthesis?" Journal of Religion 64 (1984) 188-204.

${ }^{12}$ Bracken, "Response to Elizabeth Johnson's 'Does God Play Dice?' " 721 Bracken is equally emphatıc in the latter essay" "Secondly, I would argue that the classical doctrine of analogy to which Johnson makes appeal in this case still has to employ terms that somehow apply to God as well as to creatures" ("The Theology of God of Elizabeth A Johnson" 25). 
objects to Johnson's assertion, "It is not as if God and creatures stood as uncreated and created instantiations of 'being' which is held in common by both (a frequent misunderstanding)." 13 Bracken wonders why "the assumption that God and creatures share the reality of being is 'a frequent misunderstanding.". Although he would grant that "God is the primary instantiation of being, the only entity that possesses being by nature," he asks "why cannot creatures participate in the same act of being, albeit in a finite way?"14 The issue to notice here, is not Bracken's suggestion that Johnson equivocates in her use of the term "being," but his assumptions about what constitutes equivocation and what makes for a legitimate analogy.

\section{David Burrell}

It is telling that at this step in his argument, Bracken refers to David Burrell's study on Aquinas. ${ }^{15}$ While noting that Burrell "points out, the way being is predicated of God cannot be understood from the way in which being is predicated of creatures," Bracken detects a contradiction because Burrell "likewise points out that that which is thereby signified, namely being, applies literally to God as well as to creatures." 16 First, Bracken's paraphrase is inaccurate on two counts. As I read Burrell on those pages, he says that esse applies analogically to God and to creatures. It applies literally (or properly) only to God. Moreover, it is clear from the context that Bracken identifies "literal" and "univocal," whereas Burrell most certainly does not. ${ }^{17}$ More importantly, however, calling attention to this apparent incongruity, without noting its context in the book's argument, and indeed in the research program of Burrell's career, misses the key issue. To make out what Aquinas affirms of God, it is essential first to grasp how Aquinas is using language. This is the volume's principal aim. Burrell makes a compelling case, here and in his other works, ${ }^{18}$ that al-

${ }^{13}$ Johnson, "Does God Play Dice" 11.

${ }^{14}$ Bracken, "Response to Elizabeth Johnson's 'Does God Play Dice?'” 721.

${ }^{15}$ David Burrell, Aquinas: God and Action (Notre Dame: University of Notre Dame, 1979).

${ }^{16}$ Bracken, "Response to Elizabeth Johnson's 'Does God Play Dice?' " 721, n. 6.

17 "Some students of Aquinas may have gathered from his use of esse that at least this expression offers a univocal access to God .... However proper the formula 'to be God is to be to-be' may be, it does not offer us univocal access to God. And the reason is clear: esse is not a univocal expression in spite of its substantive form. In fact, the grammar of the term diverges so startlingly from substantives generally that it can hardly be called an expression at all. So it would prove chimerical to look to esse to provide a univocal baseline on which to peg one's use of analogous expressions" (Aquinas 57).

${ }^{18}$ In addition to Aquinas, see his Analogy and the Philosophy of Language (New 
though Aquinas appealed to the analogous character of language about God, he did not have a doctrine or theory of analogy as such. Attempts to derive an implicit and consistent one from his thought are not borne out in Aquinas's texts. ${ }^{19}$ Burrell contends, however, that careful scrutiny of the way Aquinas used language, particularly his masterful employment of the logical distinctions available within the medieval repertoire, discloses that he was putting language and these distinctions to a new and revolutionary use. Burrell's Aquinas was stretching language and grammar in a very precise and rigorous manner in order to make a point and to lead to an insight that could not be attained more directly.

Burrell demonstrates this through a meticulous scrutiny of Aquinas's linguistic and logical moves, particularly in Question 3 of the Summa theologiae. This "grammatical" analysis is dense, and the conception it wishes to elucidate is subtle. As Burrell admits, "grammar remains a thin gruel." 20 For our purposes, however, it is not essential to trace the whole argument or to establish its validity. It is enough to establish that Burrell understands analogy in an entirely different way than Bracken, and that Bracken's analysis does not engage this understanding - the essential thrust of which, I contend, is shared by Johnson and many other contemporary theologians inspired by Aquinas's achievement.

Question 3 treats the simplicity of God. Burrell sees Aquinas asking whether God can be located semantically the way other realities can? Is God a body? Is God composed of matter and form? of substance and accidents? Is there any way in which he is composite or enters into compositeness with other things? Burrell traces how "in one article after another, Aquinas monitors each possible way to get hold of something: locating an object in space and time or saying anything about it." The upshot, Burrell claims, is that "God escapes our grasp on every count." ${ }^{\text {"In }}$ the case of every other reality (whether physical, mental, real, or imaginary), one can locate the thing and speak about it as a composite of matter and form, accidents and substance, potency and act, genus and species, or form and esse. The point of Aquinas's discussion is to show that God transcends this sort of description. If God is the sort of reality Christians believe God to be, that is to say, if God is the beginning and end of all things, then logically and grammatically God does not fit into any of these categories. But since such categories are the only tools available in our language and grammar for talking about realities, God included, asserting God's reality

Haven: Yale University, 1973); Exercises in Religious Understanding (Notre Dame: University of Notre Dame, 1974); Knowing the Unknowable God: Ibn-Sina, Maimonides, Aquinas (Notre Dame: University of Notre Dame, 1986).

${ }^{19}$ See particularly, Burrell, Aquinas 55-58.

${ }^{20}$ Ibid. 115.

${ }^{21}$ Ibid. 18-19. 
requires purposefully breaking the rules in a way that indirectly displays what cannot be directly described. Burrell urges us to watch Aquinas's linguistic "performance," that is to say, how he uses language and how language works, when he affirms "God is simple." This affirmation does not describe a feature or characteristic of God that we can directly grasp or comprehend. It does not enable us to fit God into the categories used to speak of every other reality. "Simplicity" does not designate a description, like hardness, height or color. "Simplicity" designates what Burrell calls a "logical" or "grammatical" distinction. Even though the term "simplicity" is a substantive and thus sounds like a quality or description of God, Aquinas uses the term as shorthand for denying that any substantives, at least as we know them, can apply to God without the significant qualification just made. If God is the beginning and end of all things, then God cannot be like other things and the grammar we use to speak of God cannot operate the way that it operates when we talk about such entities.

How then can one think of God at all or affirm anything of God without, as Bracken suggests, equivocating? Much of Burrell's analysis is devoted to teasing out the logic and transcendental grounds for such signification implicit in Aquinas's grammatical maneuvers. Underlying it all is Aquinas's insight into the real distinction between essence and existence, and the consequent recognition of esse as a distinct ontological category. Burrell argues that grammatically the insight amounts to the distinction that must be made between asserting that something is the case, and entertaining a proposition about something being the case. When we say that something is, that it exists, we are not describing any particular feature of the reality. "Exist" is not a predicate or mode of being that characterizes a thing or defines what it is. For example, formally the definition or nature of a "walking dog," is the same whether I am simply entertaining the proposition, "The dog is walking" (as I read it in a novel or conceive a hypothetical situation) or if I am asserting this of the dog that had been sitting by my desk. "The dog is walking" has the same meaning (traveling on foot at a pace slower than a run) in either case although what I intend to communicate in the two cases is significantly different. We are doing something quite different when we assert that "the dog beside me is walking," than when we merely entertain the idea of the dog walking. Burrell observes that "a proposition asserted looks just like one that is being considered," but he notes that the "act of asserting it has no structural counterpart" in our language or grammar. Yet it is this act of asserting, he concludes, that provides the proper analogue for our saying of any entity that it exists or that it has existence. ${ }^{22}$

So grammatically speaking, when I say that something exists or that it

${ }^{22}$ Ibid. 34. 
has existence, this is not predication in the normal sense (the attribution of some feature or quality to the dog) even though it looks that way if we only attend to the "surface grammar [of exist] and treat it like other predicates." 23 That is why, Burrell notes, "philosophical grammarians insist on calling it a pseudo-predicate" and why we have to be attentive to the differences in the grammar of "about" when we talk "about the dog's existing" or "about the dog walking." "About" does not work the same way in these two cases. The former is an instance of "asserting" that is a sui generis activity logically and grammatically distinct from the activity of predicating "walking" of the dog. When we predicate "walking" of the dog, we are able to specify the manner in which "walking is related to dogness. And so with all predication. But not so with '... exists.' That is why we must be wary," Burrell warns, "in our use of 'about'... . For precisely what we do not (and apparently cannot) know is 'the way in which a thing possesses its existence'." 24 Note that Burrell is not denying that "this activity asserts something about the thing itself." ${ }^{25}$ Rather he is noting the special character of this sort of assertion and that it is warranted by a grammatical analogue.

This is preeminently the case when Aquinas affirmed that in God essence and esse are identical. Burrell highlights the logically odd character of the affirmation by expressing the proposition without recourse to familiar substantives: to be God is to be "to be." In affirming that God's essence is "to be," Aquinas is not giving us a description of God in the ordinary sense of things, because "to be" is not a thing or predicate in the ordinary sense. Rather the affirmation that God's nature is to be "to be" is an implication of the notion that "God is the beginning and end of all things." Burrell argues that this is a logical or grammatical implication, because it is not based on what we know of God or on some feature of God which we have grasped. Instead it is a shorthand for Aquinas's argument already noted above that if God is to be what Christians believe God to be, then God must be a reality that transcends all the ways by which we locate every other reality through predication in terms of form/matter, substance/ accidents, and so forth. This is a way of locating what is meant by God. It also models practically how to distinguish the logic of talking about God so conceived from the logic we use to talk of created things. But in itself the assertion does not prove God's existence or describe God's existence. Scrutinizing Aquinas's arguments underscores the extent of his affirmation that "we cannot know what God is, but only what he is not."26 "Aquinas is

23 Ibid. 35.

24 Ibid.

25 Ibid.

${ }^{26}$ Summa theologiae I, q. 3, introduction, as cited in Burrell, Aquinas 13. 
walking a tightrope here. While he must state that God's nature is to-be, that statement does not let us know what such a nature is like." 27

But although "exists" is a pseudo-predicate, there is enough of an analogy between the activity of asserting and the activity of predicating to warrant the use of esse as a predicate in this extended and analogous sense. Although what "to be" signifies cannot be grasped directly in a concept, the grammatical analogy between asserting things "to be" and affirming predicates of things, enables us to stretch predication and to use substantives to talk of a thing's "being" or of God's "to be." In employing this structural analogy, however, "Aquinas does not reduce an existential assertion to a predicative one." ${ }^{28}$ Rather, he extends language to display and speak of what is beyond language's grasp. Aquinas's use of esse brings us to this linguistic impasse, as does our use of esse. "That is one accepted role of philosophical analysis: to display the limits of language not by pretending to have comprehended them, but rather by bringing one up against those limits hard enough to feel them." 29 Hence Aquinas can call on Aristotle's distinction of the relation of potency to act in order to describe the relation of essence to esse as a justification for the claim that God's essence is to be "to be." What warrants the affirmation is not that creatures and creator share the same act of "being" as if with the term "being" we grasp some thing or common denominator between Creator and creatures. There is not, in this account, some core univocal meaning for "to be" as Bracken had argued must be the case. But there is something common in the activity of asserting which can license a very restricted and analogous, but nevertheless meaningful use of "to be" for locating God as "mystery" (in the proper sense of the term as a reality known but not comprehended) and for conceiving that "to be" as the beginning and ending of all things. This stretches the meaning of "analogous" itself so that it too is not a univocal concept-or, speaking circularly, analogy is itself an analogous concept.

If one is mindful of this qualitatively different logic of signification, then it is possible on Burrell's reading to understand Aquinas's use of esse as a substantive (even "the emphatic substantive: ipsum esse" ${ }^{\text {"30 }}$ ) without thereby concluding that God is in anyway an "entity" within our grasp or that God's "act of being" must somehow be like our "being." This is possible because "being," just as terms of perfection has a range of meanings that points beyond any of the particular instances we can know. For example, we can use "living," "good," or "wise" to express many ways of being alive, good, or wise without thereby exhausting the range of these terms to encompass still other ways of living, goodness, or wisdom not yet

${ }^{27}$ Burrell, Aquinas 42.

${ }^{28}$ Ibid. 46.

29 Ibid. 50 .

${ }^{30}$ Ibid. 47. 
known or envisioned. ${ }^{31}$ We can thus distinguish the thing signified (res significata), wisdom for example, from the manner in which it was signified (modus significandi) as a particular instantiation of wisdom. Burrell contends that analogous terms such as these "have a capacity to function quite literally in diverse contexts." He explains, "For example, I can use in control' to describe the governance of a strict or of a permissive parent, employing that analogous term properly in each case. And I can recognize this situation, notwithstanding the fact that each of us tends to use the word by reference to certain paradigm situations." 32 So the range of meaning is not circumscribed by some underlying univocal sense. Analogous terms just as "wisdom" are open to a range of meanings beyond those specified in the dictionary. Burrell maintains that "the single recurring fact is that we can always find a more comprehensive use of the term. In fact, a recursive formula displays the analogous structure of these expressions, e.g., the wise man is one who realizes he is not wise. And the formula has an inbuilt ratchet-effect. The more accomplished the wise man is, the wiser he becomes in realizing that his accomplishments do not constitute wisdom." 33

Burrell argues that reflection on this ratcheting-effect of such words "can intimate a literal sense which transcends our actual employment." ${ }^{34}$ And if God is the source of all perfection, then it follows that such terms apply most properly and literally (not univocally) only to God. We know such perfections only in the limited mode of signification available to our creaturely experience. We know instantiations of wisdom, not wisdom as such. We have an analogous rather than univocal grasp of what wisdom is. What wisdom is literally or properly, on this understanding, is beyond our grasp. However paradoxical this sounds, it is not equivocating. Our experience of the range of meaning for such a term and what Burrell describes as the ratcheting-effecting of its grammar, gives us an intimation of its literal sense even though it falls short of an intuition, direct grasp, or underlying univocal description. So although we affirm such perfections of God, we do so without knowing how they signify God. It is crucial to note, that "the proper use of appropriate expressions turns not on acquaintance with divinity, but rather on a keen appreciation of the peculiar ways we must fracture logic to constitute a domain of discourse about God." 35 The knowledge of God that results is certainly limited, particularly if analysis is restricted to strictly philosophical reflection without theological appeal to revelation. But it is nevertheless for all its indirectness real knowledge. And for all its roundaboutness it is grounded in our understanding of how things are. Burrell readily acknowledges that Aquinas did not work in so

\footnotetext{
${ }^{31}$ Ibid. 64.

${ }^{33}$ Ibid. 70 .

${ }^{35}$ Ibid. 65 .
}

32 Ibid. 63.

34 Ibid. 
"highly reflective manner" as this. The interpretation presumes that "great thinkers like Aquinas do make genial moves, operating better than they know how to say." 36

The objective in rehearsing all this has not been to establish the correctness of Burrell's interpretation of Aquinas, but only to show that it puts forth an understanding of analogous predication and of esse that is entirely different from what Bracken presumes. Burrell insists that it is critical we understand what sort of signification we are dealing with in analogies for God, and particularly that we get the logic of Aquinas's use of esse right. In Burrell's reading, Aquinas "hangs literally everything upon it." ${ }^{37}$ This is very instructive for getting at the difference between Johnson's and Bracken's understandings of religious and metaphysical signification, but we do not need to hang everything on Burrell's interpretation. Johnson's essay on providence presupposes her earlier analysis of the doctrine of analogy where she provided a lucid and succinct overview of the notion in 20thcentury theology featuring in particular the work of Rahner, Przywara, Hill, and Tracy. ${ }^{38}$ She concludes, "The net result of these various studies is an understanding of analogy in the Catholic mind today that once again stresses its movement through negation towards mystery, and consequently the nonliteral although still meaningful character of its speech about God." 39 Some ambiguity could be avoided if she had said "non-univocal" instead of "nonliteral," but I agree with her conclusion about the "net result." Bracken's response to her theology suggests, however, that the common possession of this perspective in the Catholic mind today may be too sanguine. In that light, it bears emphasizing too how Rahner understands the logic of analogy as qualitatively different from what Bracken envisions.

\section{Karl Rahner}

Rahner's theology is sufficiently familiar to the readers of this journal that it is not necessary to repeat the arguments that lead him to conclude that God is the mystery toward which human knowing and love implicitly and necessarily reach but who nevertheless always remains beyond human grasp even in that reaching. For Rahner, God cannot be conceived as an entity in the world or alongside it. Johnson notes in her essay that this leads Rahner to recover a more complex understanding of analogy. "Karl Rahner refuses to understand analogy as a hybrid between univocity and equiv-

${ }^{36}$ Ibid. 53.

${ }^{37}$ Ibid. 51.

${ }^{38}$ Elizabeth Johnson, She Who Is: The Mystery of God in Feminist Theological Discourse (New York: Crossroad, 1992) 104-20.

${ }^{39}$ Ibid. 111. 
ocity; rather, he insists on the original nature of the analogical relationship that grounds subsequent speech. We exist analogously in and through being grounded in holy mystery which always surpasses us." ${ }^{20}$

In light of Bracken's critique, it might be helpful to unpack this claim to show its general congruence with Burrell's position, for Rahner argues just as emphatically that language about God has a different logical status from language about other entities. Even to use the phrase "other entities" is misleading. "The ultimate measure cannot be measured." ${ }^{41}$ For, Rahner explains in language reminiscent of Burrell's, "since it is the condition of possibility for all categorized distinctions and divisions, it cannot itself be distinguished from other things by the same modes of distinction." ${ }^{42}$ Rahner is not merely offering an apophatic reminder of God's transcendence. He insists:

Analogy, therefore, has nothing to do with the notion of a secondary, inexact middle position between clear concepts and those which designate two completely different things with the same phonetic sound.

Rather, because transcendental experience is the condition which makes possible all categorical knowledge of individual objects, it follows from the nature of transcendental experience that the analogous statement signifies what is most basic and original in our knowledge. Consequently, however familiar equivocal and univocal statements are to us from our scientific knowledge and from our everyday dealings with the realities of experience, they are deficient modes of that original relationship in which we are related to the term of our transcendence. And this original relationship is what we are calling analogy: the tension between a categorical starting point and the incomprehensibility of the holy mystery, namely, God. We ourselves, as we can put it, exist analogously in and through our being grounded in this holy mystery which always surpasses us. ${ }^{43}$

So for Rahner too, the grounds for using concepts drawn from our language about the realities of our world to talk of God are not properties we have in common with God. Nor is analogy itself a univocal concept. Our reflexive awareness of our knowing, loving and freedom reveals a kind of

${ }^{40}$ Ibid. 116, quoting Karl Rahner, Foundations of Christian Faith, trans. William Dych (New York: Seabury, 1978) 73.

${ }^{41}$ Karl Rahner, "The Concept of Mystery in Catholic Theology," in Theological Investigations 4 (New York: Seabury; orig. trans. 1966) 37-73, at 51 [Schriften zur Theologie 4 (Einsiedeln: Benziger, 1954) 51-99, at 70]. Hereafter I cite first the English translation followed by the volume and pagination of the German text in square brackets.

${ }^{42}$ Ibid.

${ }^{43}$ Foundations of Christian Faith 72-73. 
anticipation or intimation (Vorgriff) of a "whither" that always exceeds our grasp. It is the reflexive awareness of this that enables us to speak of that incomprehensible "whither," but without thereby grasping or defining it. In other words, we can identify the "whither" in terms of our movement, or transcendence, toward it in knowing, loving and self-commitment. Thomas Sheehan suggests the adjective "kinetic" to describe the movement involved in this "grasping at" or "reaching out" that always falls short of its mark. ${ }^{44}$ In light of this analogous or kinetic identification, we can speak of that toward which knowing, freedom, and love move as our "horizon," "term," or "goal." In doing so we have not literally described or defined God. For all that we truly grasp is ourselves and the openness of our spirit outwards beyond ourselves. "Analogical" in this instance means a radically indirect and reflexive manner of predication. It presupposes an inherent relatedness to God but not anything that could be properly called similarity.

Since whatever terms we use of God necessarily bear this radically indirect and reflexive reference to mystery, the predication is intrinsically analogous whether explicit in conspicuously metaphorical terms like "whither" and "horizon," or less obvious in terms like "fullness of Truth and Love" or "Being Itself." "This means," Rahner argues, "that theological statements have a special and peculiar theological relativity of their own, i.e. their radical reference to that which infinitely transcends them, such that without this reference they become meaningless." ${ }^{45}$ Accordingly, God "can be spoken of only in a qualitatively different kind of statement." 46 Like Burrell, he argues with respect to the statement "God is" that it "is not a proposition which one can range alongside other propositions which constitute science" or ordinary language because, as we have seen, its logic is of an "utterly different kind." ${ }^{, 7}$ Although Rahner is not as radical or consistent as Heidegger in distinguishing between what it is "to be" as such (Sein) on the one hand and beings "Seienden" or their beingness (sometimes rendered as das Seiende, sometimes as Sein or esse), there can be no denying that in identifying God with Sein (or esse), he thought of both as known only reflexively and indirectly. ${ }^{48}$ This reflexive knowl-

${ }^{44}$ Karl Rahner: The Philosophical Foundations (Athens: Ohio University, 1987).

45 "Reflections on Methodology in Theology," Theological Investigations 11.68114 , at 112 [9.79-126, at 124].

46 "Science as 'Confession'?" Theological Investigations 3.385-40, at 391 [3.45572 , at 461$]$.

${ }^{47}$ Ibid.

${ }^{48}$ Sheehan argues from this inconsistency for an "atheological" retrieval of Rahner's thought. Saving Rahner's God from Sheehan's critique also ultimately hinges on the metaphoric character of Rahner's fundamental metaphysical and theological moves. 
edge, he argues, is not secondary or inferior to our grasp of entities in objective concepts, but rather is the necessary condition of possibility for such objectifications-their flip side, as it were-and in a sense more original.

\section{THE METAPHORIC PROCESS}

Much more would have to be said, if our goal were a comparison of Burrell's inquiries that are mainly philosophical and Rahner's that are primarily theological. The difference in the contexts of their writings itself suggests a number of questions. There are substantive and methodological differences to be sure. The immediate goal here has been a more limited one; to show that they, and by implication Johnson, understand analogy very differently than Bracken does, and to urge that negotiating the disagreements between Bracken and Johnson requires directly engaging this difference. They do not accept Bracken's claim that analogy "requires that the entities under comparison have something in common." They question the very appropriateness of conceiving God (or "Being") as an entity that could be literally one term in a comparison. Bracken does not contest their arguments or conception of analogy. He asserts a different one and thus begs the question. His claims about how Aquinas or "classical theism" understood analogy also beg the question, since the cogency of the position of Johnson, Burrell, and Rahner as such does not hinge on whether they are accurate historical interpretations of Aquinas. A creative modification or even misreading could nevertheless be useful for articulating the Church's faith today. Bracken's subsequent arguments against Johnson hinge on his assumptions about what is logically compatible with a Thomistic understanding. Since she, Burrell, and Rahner understand the logic of analogical signification so differently, unless that issue is engaged it is not clear that any of Bracken's criticisms hit their mark.

Genuine engagement between Bracken and Johnson would require that Bracken address these issues. I have not proved that he could not, or that those who disagree with him have the better arguments. I have laid out some reasons for inquiring about what is at the root of their disagreement. I have raised this question about analogy as prelude to a larger objective: to characterize Bracken's and Johnson's positions as representing a choice between two fundamentally different views of what constitutes religious and metaphysical signification.

At least on the surface of it, the circularity of the positions of Burrell and Rahner is somewhat confusing: their explanations of analogy appeal at crucial moments to the analogous character of analogy itself. To get a better sense of how these arguments about analogy work and the kind of signification that is involved, it is helpful to take a hint from Burrell's own methodology, to step back from what he and Rahner say about analogous 
statements, and to examine their performance. What is at the root of this shift in meaning that they propose? Mary Gerhart and Allan Melvin Russell's description of the "metaphoric process" provides a way of clarifying this. ${ }^{49}$ Their proposal summarizes and builds on an extensive body of research in philosophy and literature on metaphor but leads to an innovative conception of what metaphor and analogy are and how they come about. The immediate context of their discussion is the relationship between science and religion. Paul Ricoeur comments that the "most remarkable contribution" of their theory is the proposal that metaphor is the manifestation of a fundamental epistemological process underlying the creation of new understanding in both disciplines. The decisive step, he notes, is the role metaphor plays in changing the fields of meaning in an inquiry. Rather than merely augmenting what is already known, metaphor actually creates the possibility for new meanings and understanding. ${ }^{50}$

The argument presupposes that our inquiries about the world and ourselves take place in what can be imagined as cognitive spaces or worlds of meanings. These worlds of meanings are made up of networks of interrelated concepts. Physics, theology, a religion, or common sense as defined by a particular time and culture are examples of such fields of meanings. The concepts within these fields do not stand directly for things in themselves, but for our notions of these things. These notions are defined by their interrelation with other notions. For example, to get some conception of "house," one must have other notions available (lumber, bricks, tin sheets, wall, window, roof, etc.). These other notions are variable, as well as the relations between them, so that "meaning, then, arises out of the interaction of concepts and relations, and is expressed in the topography of the field. Necessary concept changes, such as those which might arise from a new experience, alter relations; and changes in relations, such as occur when one attempts to understand an experience in a new way, relocate old concepts." ${ }^{51}$ For example, "house" is likely to give rise to a somewhat different idea and set of associations for a middle-class North American exchange student who has just spent time living in a barrio. Likewise "soul" and related notions vary significantly among Christians, Hindus, and Animists so that despite some similarities between the concepts, it cannot be assumed that a Hindu or a Christian share the same notion. Even among those who share a world of meanings, the understandings of such notions

${ }^{49}$ See Mary Gerhart and Allan Melvin Russell, Metaphoric Process: The Creation of Scientific and Religious Understanding (Fort Worth: Texas Christian University, 1984); and their further elaborations of the theory in "The Cognitive Effect of Metaphor," Listening 25 (1990) 114-26. See also: New Maps for Old: Explorations in Science and Religion (New York: Continuum, 2001).

${ }^{50}$ Metaphoric Process xii.

51 "The Cognitive Effect of Metaphor" 119. 
can vary somewhat from person to person, depending on factors such as education and linguistic sophistication. Moreover, the meanings can change over time if new associations are made between existing notions, or if a new notion is added to a field of meanings. For example, in the Gospels when Jesus identifies the notion of Messiah with that of the Suffering Servant, the association significantly alters not only these notions but, as well, a host of other notions related to the idea of eschatological expectation (a field of meanings), if not the very fabric of Jewish faith (a still broader field of meanings). ${ }^{52}$

In the view of Gerhart and Russell, a world of meanings is made up of collections of such fields of meanings and it "comprises the basis for an individual's idea of the way things are." ${ }^{53}$ The theory regards the individual's or community's construal, when it is successful, as corresponding in a genuine but complex way to reality. On the other hand, the theory also holds that "worlds of meaning are culture-bound. Within a particular culture, persons have worlds of meanings that have the same general topography despite the fact that a particular field of meanings possessed by one person may be completely absent in another." ${ }^{, 54}$ What interests Gerhart and Russell is how new understandings and meanings develop among people who share such a world of meanings. They distinguish the discovery of new meanings from the acquisition of new knowledge that involves merely an addition of data that does not change the notions or fields of meanings themselves. For example, we can learn of new cities or new planets and so gain additional information for ourselves or the field of astronomy. In doing this, however, we usually do not change the notions of "city," "planet," or "solar system." In contrast, Copernicus's insistence that the sun is the center of the universe or Newton's insistence that the mechanical laws of the heavens are identical with the mechanical laws of the earth, created new understandings that changed fundamental notions within physics and indeed changed how ordinary people understood things. Much of the routine work of scientists and theologians is devoted to the former sort of acquisition aimed at expanding the current knowledge base. Insights of the latter sort are occurrences of genius and discovery typically associated with more extraordinary and consequential developments in a

52 To what extent such alterations in meaning were effected, whether by Jesus or later interpreters, with what justification and with what success are of course the fault lines of disagreement from which Christianity developed as a new religion and that continue to divide traditions of beliefs and schools of scholarship. That different historical and theological answers to such questions are possible, does not alter the fact that a metaphoric identification underlies the possibility of such new meanings and understandings.

53 "The Cognitive Effect of Metaphor" 120.

54 Ibid. 
field. Analogy, broadly conceived, plays a key role in both processes. A crucial element of Gerhart and Russell's proposal is the suggestion that we distinguish between three different though related ways of making an "analogy" that we can designate as "analogy," "simile," and "metaphor." 55

In Gerhart and Russell's scheme "analogy" and "simile" are conceptual tools that often play a key role in the former task, the acquisition of additional information. In this context they use "analogy" in a more restricted sense than Burrell and Rahner-closer, in fact, to the notion Bracken presupposes. Analogy in this definition involves the use of some feature common to a known " $x$ " and a known " $y$ " to extend or expand our knowledge of either " $x$ " or " $y$ "- -or, in some cases, both. Successful analogies between the operations of the human mind and computers, for example, could lead either to a better grasp of how the mind works, to the development of more sophisticated software, or to an enriched understanding of both analogues. In my view, Bracken appears to understand his modification of the Whiteheadian conception of intersubjectivity as this sort of analogy with the Christian notion of God. Such analogies should be taken seriously and can be instructive, at least when successful, but, as Bracken notes, they do not provide literal descriptions. A computer program that simulates thought processes is not actually thinking, nor is it a literal map of thinking. A similar caveat would apply to Bracken's analogy between intersubjectivity and the trinitarian God of Christian faith.

Sometimes, only one of the analogues in question will be known. In that case, a known feature of " $x$ " tells us something about " $y$ " which is unknown. This is what Gerhart and Russell understand to be the defining characteristic of simile. "So when Max Black wrote, 'The chairman plowed through the discussion,' he created a text that instructs the reader who does not know how the discussion proceeded, and who now, on the comparative basis of the simile, does know," presuming, of course, that both are familiar with the use of a plow. ${ }^{56}$ Whether Black's proposition functions as an analogy or simile depends on the knowledge state of the persons involved. A person who was present at the chairman's discussion would be in a position to agree with Black's analogy or, as we say, to "get" the analogy and acquire a deeper insight into the event. That person, however, would not be acquiring new information about something unknown.

Gerhart and Russell note that with these definitions a great many of the comparisons we ordinarily think of as metaphors are, in their theory, either

${ }^{55}$ Although they have not explicitly designated these as three kinds of analogy in their published writings to this point, they have assured me that this is an accurate way of describing their distinction.

${ }^{56}$ Ibid. 116 quoting Max Black, Models and Metaphors: Studies in Language and Philosophy (Ithaca, N.Y.: Cornell University, 1962) 13. 
analogies or similes. The metaphoric process involves a third kind of analogy where, given the normal understanding of the notions within or between fields of meaning, there is no acknowledged similarity between a known " $x$ " and " $y$." When such a situation obtains, saying that " $x$ is $y$ " forces an analogy between the two knowns that is uncalled for. "In our cognitive network, the metaphoric process forces relations in one part of a field to be isomorphic with another part, thereby creating a similarity or analogy where none existed." ${ }^{57}$ The distinguishing character of metaphor is that it distorts the given world of meanings. Once one gets the point of the metaphor-gets the point of affirming that " $x$ is $y$ "-then "x," "y," and the coordinates (or field of meanings) in terms of which we had formerly understood them, are comprehended in a new way which makes it possible to conceive notions, understand relations, and envision as logical what could not have been so grasped before the metaphoric act. Gerhart and Russell stress that "it is of particular importance to see that it is the theoretical structure of the meanings involved in metaphor that makes new knowledge possible. The distortion of the fields of meanings by means of the metaphoric process is a structural change that demands that other meanings and understandings have to be changed in the wake of the metaphor." 88 They contend that "this is what is so different about the metaphoric process. Analogy, on the other hand, is an extension of meaning (as distinct from the creation of new meaning). The increased knowledge from analogy is primarily in terms of the original understandings."

Take the example of the early Christians' affirmation that "Jesus is the Messiah." ${ }^{60}$ Given the images current in the eschatology of the day, affirming that God was victorious in the crucified son of a carpenter from Nazareth was uncalled for. In fact most of the key eschatological images by which Jesus is identified in the Gospels have something of this metaphoric dimension. By ordinary logic he was not a victorious King of Israel; he was not a Son of Man who descended gloriously from the heavens; he was not acknowledged by his people nor did he vanquish their enemies. To affirm that Jesus is the Messiah is to force an analogy between him and Israel's expressions of hope and trust in God. Forcing the analogy requires us to understand differently both Jesus and that hope itself. Affirming that Jesus is the Messiah, if taken seriously, forces a thoroughgoing revision of the field of meanings operative in Palestinian Judaism, or at least those operative in the narrative worlds of the New Testament. Given that shift in meaning, it is appropriate to say that Jesus literally and properly is the

57 Ibid. 121.

${ }^{58}$ Metaphoric Process 119.

59 Ibid.

${ }^{60}$ I believe for our purposes here the exact Sitz im Leben of the original affirmation is immaterial. 
Messiah. This is not just a symbolic claim or metaphor. But neither is the shift of meaning simply a given. It is a result of a metaphoric forcing of an analogy that many non-Christians and historians, among others, do not accept. From their perspective it is not true that Jesus is literally the Messiah. Since the metaphoric act creates a shift in meanings, however, it would be misleading to focus an inquiry merely on the question of whether "Messiah" is used univocally (and so incorrectly) or equivocally (and so to no effect) by Jesus' followers. An account that did not take into consideration the logic of this underlying metaphoric process would be inadequate for the task.

According to Gerhart and Russell, Copernicus brought about a similar shift in scientific understanding:

"The sun (not the earth) is the center of the solar system." This is not a simile, nor is it an analogy. Furthermore, there is nothing unknown or ambiguous about "the sun," nor about "center of the solar system." To insist, on the basis of no observational evidence, that one of the concepts is the other, conforms to our description of the linguistic expression of a metaphoric act. The identity between two hitherto different but known concepts changed a host of relations in fields of meanings and reformed the topography of the world of meanings. Testimony to the outrageous act is amply given in history's descriptions of the reaction of religious authorities. ${ }^{61}$

They argue that Newton's equation of the mechanical laws of the heavens with the mechanical laws of the earth "had perhaps an even more profound effect on our lives" 62 and that it was in similar ways metaphoric.

\section{METAPHORIC SIGNIFICATION IN BURRELL, RAHNER, AND JOHNSON}

If one steps back from what Burrell and Rahner say about analogous statements and examines the shift in meaning that they propose, it too can be explained as a metaphoric act. Both force the analogy between reflexive knowing on the one hand and knowledge of objects on the other, insisting that the former is the proper model for speaking of God and that it is meaningful even though it does not literally grasp God. Burrell, as we have noted, calls attention to this reflexivity of knowing by focusing on the grammar of asserting as distinct from the grammar of predication. Asserting and predicating are the two knowns. In his analysis, the metaphoric act consists in insisting that the former (asserting) provides the grammatical analogue for explaining propositions like "John exists" or "God's essence is to be "to be'" even though these look like normal predications (the latter). Forcing this analogy opens up space in the available fields of mean-

\footnotetext{
61 "The Cognitive Effect of Metaphor" 124.

${ }^{62}$ Ibid.
} 
ings (or Burrell might say, in the available grammar) to speak of an unknown, God, without thereby getting that unknown directly in our grasp. Forcing the analogy does not add God as an object to the scheme of known objects nor does it add an objective description of God to our inventory of known entities. Forcing the analogy provides us with a different way of understanding the relation between what we intend when we use "God" and the objects grasped through ordinary predication schemes. It leads to a very different understanding of the kind of signification that is entailed when we speak of God or esse. ${ }^{63}$

While Burrell focuses on the hints of reflexivity implicit in grammar, Rahner's more directly metaphysical and epistemological analysis calls attention to the reflexivity implicit in the intentionality of knowing, love, and freedom. ${ }^{64}$ This also fits Gerhart and Russell's conception of a metaphoric act. The first known is what Rahner calls "transcendental knowing"-the reflexive, indirect and kinetic presence-to-self and anticipation (Vorgriff) of the horizon of knowing, love, and freedom. The second known is the knowledge of objects or "categorial knowing." Rahner forces an analogy by insisting that the model for knowing and speaking of God (or Being Itself) is transcendental knowing rather than categorial knowing, and that the former is not a derivative, secondary or inferior way of knowing. Forcing the analogy, that is to say speaking of God as "transcendental reality" creates a logical space for talking of God even though as Holy Mystery God is still beyond our grasp. The logic of God-talk is governed by the intrinsic reflexivity and indirectness of this metaphoric signification. This must not be forgotten lest one fall into the mistaken notion that transcendental reality is a transcendental "object" that can be known, spoken of or described the way we know and speak about categorial objects. Rahner's use of terms like "Holy Mystery," "nameless whither," "horizon" and "asymptotic goal" are meant to call attention to this metaphoric shift in sig-

${ }^{63}$ One could argue that Burrell furthers our understanding of Aquinas's metaphor by a secondary metaphoric act. He forces an analogy between Wittgensteinian analysis and Thomistic metaphysics in urging that Aquinas's metaphysical statements about God are an instance of grammatical analysis. In so doing, Burrell opens up space for new way of reading Aquinas. The maneuver alters both Wittgensteinian and Thomistic fields of meaning creating unanticipated possibilities for mutual engagement and enrichment. Making the case that this is also an instance of the metaphoric process, however, is not essential to the my argument and so I mention it only in passing. It could be argued that there is something metaphoric, as well, as in the way Rahner insists on an identity between Aquinas's ipsum esse and a notion of "being" (Sein) indebted to Kant and Heidegger.

${ }^{64}$ This is not to say that such grammatical hints cannot be found in Rahner's thought as well. Ann Riggs makes a persuasive case for this in her Ph.D. dissertation "Rahner, Self, and God: The Question of the Cartesian Ego in the Theology of Karl Rahner" (Marquette University, 1998). 
nification. Moreover, characteristic of metaphoric signification, affirming that God is transcendental reality effects fundamental and global changes in the available theological and metaphysical fields of meanings.

Likewise, failure to take into account the metaphoric character of this sort of analogical predication is bound to distort interpretation of Johnson's proposal about providence. An attentive reading indicates that she presupposes Rahner's metaphoric insistence that the ground for analogous speech about God is that we ourselves "exist analogously." 65 This shift in fields of meanings underpins the logic of her argument "that divine providence is compatible with genuine randomness and that this compatibility in turn can shed light on the incomprehensible, gracious mystery of God." ${ }^{66}$ Without this fundamental shift in meanings her moves are indeed contradictory. I believe the shift also explains her insistence on the importance of naming God "She Who is," and her resistance both to the suggestion that we merely avoid gendered speech for God or to Bracken's recommendation that we use the expression "the Three Who are One." ${ }^{\text {"67 }}$ The goal of her effort is not simply to propose a more fitting analogy for God or a more apt metaphor (in the sense of mere linguist trope or figurative analogy). Her insistence seeks to force a shift in the theological and religious fields of meanings and thus bring to the surface a fuller sense of God's mystery, of God's identification with us-female and male-and to expose the wounds of sexism in the Church's life and thought. Johnson's discussions of analogy and metaphor do not explicitly articulate, as Gerhart and Russell do, the underlying transformation in fields of meanings at the heart of the metaphoric process involved in this appeal to analogy. Perhaps an inattentive reader could even be misled by the lucidity of her explanation of analogy as a threefold motion of affirmation, negation, and eminence. This movement could be (mis) understood as simply an elaboration of the sort of analogy that provides an extension of meaning, even if in a "supereminent" way, within a given field of understanding but that does not create new meanings or the possibility for new understanding as the metaphoric process does. Johnson's insistence that "the analogical process is a dynamic of relational knowing" accomplished in judgment rather than in a concept ${ }^{68}$ and her reference to Rahner's understanding of analogy later in the chapter, indicates otherwise. However, I suspect that this notion of analogy may not be understood clearly or widely enough to preclude the possibility of such a misreading. ${ }^{69}$

65 She Who Is 116.

66 "Does God Play Dice?" 4.

67 "The Theology of Elizabeth Johnson" 31.

${ }^{68}$ She Who Is 114.

${ }^{69}$ Bracken, for example, did not seem to get the significance of this from 


\section{THE COMPLEXITY OF ANALOGICAL AND METAPHORIC SIGNIFICATION}

If we grant Gerhart and Russell's theory, then a distinction must be made between two different epistemological processes that use analogies. What they refer to as the "analogical act" involves recognition of similarities (analogies) within or between given fields of meanings. When successful the analogical act expands meanings within those fields without distorting the fields. The "metaphoric act" also involves the recognition of similarities, but these similarities are the result of a "disruptive cognitive act" that forces an uncalled-for analogy within or between the fields of meanings-a distortion of one or both of these fields in order to achieve the required analogy. When this distortion is productive it creates new understandings and meanings. This classification, though, is not quite as neat as one might wish, since both processes involve analogies. Moreover, although the classification has offered a way of distinguishing the sort of analogical relationship that Bracken has in mind from the sort that Burrell, Rahner, and Johnson have in mind, applying the distinction requires some interpretative effort since none of them makes the distinction themselves. Sometimes, for example, Rahner uses "analogous" in the first sense while at other times by "analogous" he intends "metaphoric" in Gerhart and Russell's sense.

Things become more complicated when two other factors are taken into consideration. First, as a successful metaphoric act gains acceptance and begins to effect permanent transformations in a field of meanings, the uncalled-for analogy becomes more and more obvious. After a while, it is taken for granted. It becomes a "given" in the new but now stabilized field of meanings. The metaphor dies or perhaps more accurately is transformed into an analogy, simile, or univocal concept. It was a metaphoric act for Copernicus to insist the sun is the center of the solar system, or for Newton to insist on the identity of heavenly and earthly mechanics. Such insistence would not constitute a metaphoric act today.

That the propositions could be metaphoric for Copernicus and Newton but univocal for us suggests the second complication: whether the act terminates in metaphor, analogy, simile, or a univocal concept is determined in part by the knowledge state of the person entertaining it. As we saw with Black's example of the chairman plowing through a discussion, an analogy becomes a simile if the people entertaining the proposition were not at the discussion. Likewise, the persons must know both sets of relations for a

Johnson's reiteration of these points at the CTSA discussion, since his references to the doctrine of analogy later that year at the AAR still do not recognize that Johnson has proposed a different sort of analogical predication. 
metaphoric proposition to create a distortion in their fields of meanings. If they know only one of the two metaphoric elements, the proposition "functions as an analogy, since the unknown element is free to move within the field. Such freedom removes the possibility of tension or distortion of the field of meanings. ..." A0 Alternately, if the persons involved have different linguistic sensitivities or only appear to share fields of meanings, and because of different backgrounds or presuppositions understand one or the other of the terms differently, then what for one person is a metaphor, for a second could be merely an analogy, while a third might take the proposition as univocal.

That could be the case, for example, with the Christian insistence that Jesus is the Messiah. This confession as a metaphor challenges us fundamentally to reconfigure our understandings of Jesus, of God's love, and of humanity's relation to both. A secular historian could understand the same proposition as merely an analogy, perhaps in some ways justified, in other ways not. The proposition could also be taken naively as asserting a univocal identification of Jesus and the Messiah. A historically naive believer might affirm the proposition that way, while an unbeliever who also takes the assertion as a univocal identification would likely deny it. What those two would have in common on this reading is not that both interpret the assertion literally, but that both miss its metaphoric character, or at least potential. Someone like myself who affirms the metaphoric character of the proposition, is not denying its appropriateness to Jesus, but only specifying the logic by which it can be said properly and literally of him. The metaphoric and literal are not necessarily opposed unless literal and univocal are identified. When as a Christian theologian I insist on the metaphoric character of the claim that Jesus is my Lord and Messiah, it is not to say less-certainly not to deny he is the Messiah-but to open up a field of meanings that enables us to say more.

Gerhart and Russell conclude from these kinds of considerations that, if metaphor and analogy are viewed as cognitive processes, "reception" has to be taken into account to understand what is being signified. Although Bracken does not ignore the historical and conceptual contexts of his interlocutors, it appears that in his view of analogy it is possible to talk about what a given idea of God logically demands without taking into consideration how the significance or logical entailments of that idea might be qualified by fundamental shifts of understanding in the theoretical horizons of meaning in which the idea is proposed or in the personal horizons of those entertaining the idea. Noting the importance of "reception" in the metaphoric process does not enjoin the kind of metaphysical and theological engagement Bracken seeks between process thought and other per-

70 "The Cognitive Effect of Metaphor" 121. 
spectives. Nor does this position undermine logical or metaphysical rigor. Rather my position speaks to the care that must be taken in such comparative analysis and suggests something of the complexity involved in comparing the logic of different metaphysical conceptualizations. It speaks to the need for a theory of metaphysical and theological signification that can account for this sort of complexity. Finally, it speaks to the importance of clarifying how it is that language and thinking signify God in the first place. Fundamental disagreement about that is likely to preclude, or at least confuse, meaningful dialogue on other issues.

\section{THE LOGIC AND LIMITS OF ENTITATIVE ANALOGIES}

Bracken had characterized the difference between Johnson's position and his as the choice between a worldview governed by the logic of objective cause-effect relationships and one governed by the logic of intersubjectivity. The point of my analysis has been to show that the difference would be described more fundamentally and accurately as the choice between a worldview governed by the assumption that metaphoric signification provides the only proper logic for speaking and thinking of the mystery of God and a worldview governed by the logic of entitative analogies.

The first worldview, as we have seen, holds that the only way to speak of God, or being-as-such (esse, Sein) for that matter, is by stretching language to the limits. The analogies that result from such metaphoric thinking do not grasp the reality as such, but nevertheless by a twist of thought, reflexively and indirectly point to what is in question. As Rahner's works demonstrate, the metaphoric character of these analogies does not preclude the possibility of rigorous and robust "metaphysical" argumentation even though being-as-such always remains beyond the grasp of human concepts. But attention to this argumentation's distinctive transcendental logic is crucial to correctly understanding it. This worldview, for both philosophical and theological reasons, holds that God cannot be conceived as an entity in the world or alongside it. To say that "God is," is not to say that God is a created being or an entity directly analogous to created beings. Inevitably, because of the limits of human knowing and language, we speak as if God were an entity or being, but correct interpretation requires that the metaphoric character of such talk, and consequently its distinct logic, must always be kept in mind. Hence, talk of God as the Supreme Being or the identification of God with being-as-such, properly understood, does not postulate either being or beingness as a determinable and univocal common denominator between creature and Creator. There is not that kind of direct analogy or isomorphism between creature and Creator or between 
beings and being-as-such even though the convictions of Christian faith lead to a metaphoric insistence on such analogies. ${ }^{71}$

Bracken's position appears to stake out a different worldview that holds it is possible to make some sort of analogy between God and other entities. Although God in this view clearly transcends other entities and is not literally observable, Bracken presumes that creature and Creator must have something univocal and identifiable in common, because the principle of analogy requires it. ${ }^{72}$ It would be inaccurate to say that his worldview lacks any metaphoric dimension at all. Although we have given little attention to it here, there can be no question that a fundamental shift in fields of meanings is proposed in process philosophy's affirmation "that being is an activity rather than an entity." That this perspective initially seems so counter intuitive yet, on further reflection, so suggestive is an obvious indication of a creative disruption in our fields of meanings. The two knowns are "beings" and the "activity which beings instantiate" (or substance and process). The world does indeed look different, and a new metaphysics is possible, if we take seriously this insistence that being is an activity. But the field of meanings is still a metaphysics concerned with entities and the activity common to entities. The field of meanings is still what Thomas Sheehan calls "ousiology," the beingness of beings. Process theology does not open up a new field of meanings in which Being (Sein in Heidegger's sense or esse in Burrell's and Rahner's, if not Aquinas's sense) can be thought of as different from beings (Seiende) or from the beingness of beings (die Seiendheit des Seienden). That is to say, the analogy is still with finite beings whether the underlying model of being is entities or the activity that entities instantiate, whether substance or process, whether beings or beingness. I do not think there is any question that Heidegger would have objected that this conception of "process" remains at the level of onto-theo-logy, because its concern is still with general ontology: with the beingness of beings not with the prior sense of Being (Sinn des Seins), and with a God conceived as the entity who is the primary instantiation of being(ness) so conceived. ${ }^{73}$ Heidegger proposed that thinking Being and God requires a more fundamental kind of thinking. A "beetle-browed

${ }^{71}$ This of course implies a non-foundationalist reading of Rahner's and Burrell's arguments but again it is beyond the purview of this article to demonstrate that. Burrell provides his own argument in "Religious Belief and Rationality," in Rationality and Religious Belief, ed. C. F. Delaney (Notre Dame: University of Notre Dame, 1979).

${ }^{72}$ The Divine Matrix 37.

${ }^{73}$ I believe Bracken's effort to appropriate Heidegger's thought in the third chapter of The Divine Matrix suffers from the same kind of misreading of metaphoric signification that we have seen in his interpretation of contemporary Thomists. Heidegger's thought from beginning to end focused on the intrinsic elusive- 
Heideggerian" would suspect that Rahner is also guilty of a "forgetfulness" of this ontological difference. ${ }^{74}$ A Rahnerian nevertheless would still object that Bracken's conception of being, and surely his conception of an entitative reality of God distinguishable from the divine nature or being(ness) that it instantiates, proposes an ontic (categorial) model that is inappropriate for an ontological (transcendental) reality. Rahner, Burrell, and Johnson would insist that esse and God require a different kind of signification. Bracken's worldview uses a metaphor to reconceive God and being(ness) but not to reconceive the thinking of God and being-as-such. From the point of view staked out in the first worldview, that sort of entitative analogy and logic could never do justice to the elusiveness of being-as-such or the transcendence and mystery of God.

Bracken's remarks about his own interpretation of Aquinas apply to my interpretation of his discussion with Johnson. "Naturally, these arguments between the adherents of rival schools of thought about their respective strengths and weaknesses are never conclusive. Further arguments can always be adduced from both sides either to bolster one's own position or to expose the weakness of the other side." 75 If he is to get the other side's attention, however, he will have to address their convictions about how we know and speak of God. If conversations between these two world views are to contribute to a more general theological consensus about the doctrine of God or to academic and pastoral dialogues between religion and science, then, at minimum, greater clarity is required about their respective understandings of the logic of metaphoric and analogical signification. The aim here has been to lay the groundwork for that sort of clarification.

ness of Being (Sein). Bracken's identification of Heidegger's Being with the activity or process that beings instantiate and his suggestion that this is what Heidegger meant by insisting that Being is No-thing belies the overwhelming thrust of Heidegger scholarship that sees that very line of interpretation precluded by Heidegger's unremitting efforts to clarify first that the "Being question" is not about Being but about the difference between beings and Being, and then that it is about the difference-as-such, and then about event of truth, and so forth. Bracken's references to William Richardson's Heidegger: Through Phenomenology to Thought (The Hague: Martinus Nijhoff, 1967) has something of the same irony as his citation of Burrell, since I understand Richardson to be arguing that the key to understanding what Heidegger means by Being is to follow how Heidegger displays the relation between thinking and Being that strictly speaking always remains the "unthought."

${ }^{74}$ The phrase is William Richardson's in an essay asserting this about Lonergan ("Being for Lonergan: A Heideggerian View," in Language, Truth and Meaning, ed. Philip McShane [Notre Dame: University of Notre Dame, 1972] 272-78, at 277). The contention that this was true of Rahner was the thrust of my article written as a student of Richardson ("Rahner and Heidegger: Being, Hearing and God," The Thomist 37 [1973] 455-88). It is also central to Sheehan's argument.

${ }^{75}$ The Divine Matrix 28. 


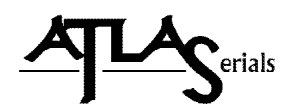

Copyright and Use:

As an ATLAS user, you may print, download, or send articles for individual use according to fair use as defined by U.S. and international copyright law and as otherwise authorized under your respective ATLAS subscriber agreement.

No content may be copied or emailed to multiple sites or publicly posted without the copyright holder(s)' express written permission. Any use, decompiling, reproduction, or distribution of this journal in excess of fair use provisions may be a violation of copyright law.

This journal is made available to you through the ATLAS collection with permission from the copyright holder(s). The copyright holder for an entire issue of a journal typically is the journal owner, who also may own the copyright in each article. However, for certain articles, the author of the article may maintain the copyright in the article. Please contact the copyright holder(s) to request permission to use an article or specific work for any use not covered by the fair use provisions of the copyright laws or covered by your respective ATLAS subscriber agreement. For information regarding the copyright holder(s), please refer to the copyright information in the journal, if available, or contact ATLA to request contact information for the copyright holder(s).

About ATLAS:

The ATLA Serials (ATLAS $®)$ collection contains electronic versions of previously published religion and theology journals reproduced with permission. The ATLAS collection is owned and managed by the American Theological Library Association (ATLA) and received initial funding from Lilly Endowment Inc.

The design and final form of this electronic document is the property of the American Theological Library Association. 